\title{
Leucomalácia periventricular e diplegia espástica: implicações nas habilidades psicolingüísticas***
}

\author{
Periventricular leukomalacia and spastic diplegia: implications in the \\ psycholinguistic abilities
}

Dionísia Aparecida Cusin Lamônica*
Plínio Marcos Duarte Pinto Ferraz**

*Fonoaudióloga. Professora Associada do Departamento de Fonoaudiologia da Faculdade de Odontologia de Bauru da Universidade de São Paulo. Endereço para correspondência: Via Puccini, 1-16 - Residencial Tivoli I Bauru - SP - CEP 170530-095 (dionelam@uol.com.br).

**Neurologista. Especialista pela Sociedade Brasileira de Pediatria. Médico do Hospital Estadual de Bauru.

***Trabalho Realizado na Faculdade de Odontologia de Bauru da Universidade de São Paulo.

Artigo Original de Pesquisa

Artigo Submetido a Avaliação por Pares

Conflito de Interesse: não

Recebido em 28.05.2007. Revisado em 24.07.07; 06.09.07; 06.11.2007.

Aceito para Publicação em 06.11.2007.

\begin{abstract}
Background: spastic diplegic cerebral palsy (D-CP) is frequently related to periventricular leukomalacia (PVL), which usually affects the descending motor fibers of the association cortex and association fibers of the visual, auditory and somesthesic functions. Aim: to verify the performance of children with D-CP regarding their psycholinguistic skills. Method: participants were eight individuals of both genders and with chronological ages varying from four to six years, diagnosed with D-CP, having PVL confirmed through magnetic resonance. These children were evaluated through the Illinois Test of Psycholinguistic Abilities (ITPA) and the Peabody Picture Vocabulary Test (PPVT), considering the cognitive performance, the level of motor impairment and the performance in the auditory and visual subtests of the ITPA. Results: the results pointed to a significant correlation between the cognitive performance and the PPVT. The same correlation was confirmed between the PPVT and the subtest of auditory reception of the ITPA, when considering the psycholinguistic age. In the comparison between the auditory and visual abilities, the participants demonstrated a better performance in the activities that involved visual abilities, indicating a significant correlation in the association subtest. There was a statistically significant correlation between the level of motor impairment and the psycholinguistic performance, confirming the influence of the motor impairment in these activities. Conclusion: the children with D-CP and with suggestive signs of PVL presented deficits in the psycholinguistics abilities, justifying the need of additional studies in this area in order to investigate the development of these abilities.
\end{abstract}

Key Words: Cerebral Palsy; Periventricular Leukomalacia; Child Language; Language Development Disorders.

\section{Resumo}

Tema: a paralisia cerebral espástica do tipo diplégica (PC-D) é freqüentemente relacionada à Leucomalácia Periventricular (LPV), a qual geralmente afeta fibras motoras descendentes do córtex de associação e fibras de associação das funções visuais, auditivas e somestésicas. Objetivo: verificar o desempenho de crianças com PC-D quanto às habilidades psicolingüísticas. Método: participaram deste estudo oito indivíduos de ambos os sexos e idade cronológica variando de quatro a seis anos, diagnosticados como PCD, confirmadas na ressonância magnética a lesão tipo LPV. Foram avaliados por meio do Teste de Illinois de Habilidades Psicolinguísticas (TIHP), Teste de Vocabulário por Imagens Peabody (TVIP), considerando o desempenho cognitivo, o grau de distúrbio motor e o desempenho nos subtestes auditivos e visuais do TIHP. Resultados: os resultados apontaram correlação significante entre desempenho cognitivo e TVIP e a mesma correlação foi confirmada entre o desempenho do TVIP e o subteste de recepção auditiva do TIHP, considerando a idade psicolingüística. Na comparação entre as habilidades auditivas e visuais, os participantes tiveram melhor desempenho nas atividades que envolviam habilidades visuais, confirmando a correlação significante no subteste de associação. Houve correlação estatisticamente significante entre o grau de distúrbio motor e o desempenho psicolingüístico, confirmando a influência do distúrbio motor nestas atividades. Conclusão: as crianças com PC-D e sinais sugestivos de LPV apresentaram prejuízo nas habilidades psicolingüísticas, justificando a necessidade de estudos adicionais nesta área com o intuito de conhecer melhor o desenvolvimento destas habilidades.

Palavras-Chave: Paralisia Cerebral; Leucomalácia Periventricular; Linguagem Infantil; Transtornos do Desenvolvimento da Linguagem.

Referenciar este material como:

Lamônica DAC, Ferraz PMDP. Periventricular leukomalacia and spastic diplegia: implications in the psycholinguistic abilities (original title: Leucomalácia $\sum 3$ periventricular e diplegia espástica: implicações nas habilidades psicolingüísticas). Pró-Fono Revista de Atualização Científica. 2007 out-dez;19(4)357-62. 


\section{Introduction}

The spastic diplegic cerebral palsy (D-CP) is more common in prematures, having direct relation between prematurity and risk for diplegia(1). Premature newborn can present hemodinamic and respiratory instability resulting in periventricular leukomalacia (PVL), having a significant correlation between motor disturbance intensity and PVL extension(2-3). Injuries in the D-CP represent ischemic damage of the periventricular zone, limited to the dorsal and lateral descendents tracts, and to the lateral ventricles. They affect, generally, the cortex descending motor fibers and association fibers of the visual, auditory and somesthetic functions, what brings impact for the perceptive abilities development intervening with the psycholinguistics abilities(4-5).

Studies have presented the relation of PVL and visual and auditory cerebral damages for the proximity of these regions. The consequence of this involvement can affect the oculomotor coordination, in the visual-cognitives complex and auditory functions(6-12), having a significant correlation between the motor disturbance intensity and the PVL extension, but not regarding to the intellectual level, that tends to be preserved $(5,13$ $15)$. Despite the individuals with D-CP formed a heterogeneous group regarding the abilities performance, the nature of perceptive disabilities and the impact in the life of these individuals needs more studies(4, 7, 16-18).

As the motor alterations consequences, the children can loose opportunities to make possible their linguistic repertoire, therefore this occurs for integrated actions of the proper organism to the psychomotors disposals, influencing maturational process and, consequently, the development of the auditory, visual and somesthesic information processing, with important consequences for the general learning $(7,12,19-23)$.

Ahead to the exposed up to now, the aim of this study was to verify the performance of children with D-CP in their psycholinguistic skills.

\section{Method}

The project was approved by the Committee of Ethics in Research with Human Beings and protocolled in 28/06/2001.

Inclusion criteria: D-CP; Exams for image confirming the PVL; Normal hearing and visual sharpness allowing the evaluation proposal accomplishment; To be aged between four and six and do not present epilepsy.

The casuistic was constituted by 8 individuals with D-CP, aged between 4 to 6 years; $62,5 \%$ of male and $37.5 \%$ of female, all with prematurity and low weight at birth time; $75 \%$ of the participant was students of public school (PS) and $25 \%$ of mixing school (MS), in other words, they attend to public school and receive psychopedagogical attendance in specialized schools. All frequent the APAE Rehabilitation Centers and receive attendance of Speech and Hearing Pathology, Neurology, Occupational therapy, Physiotherapy, Hydrotherapy, Equoterapy and Psychology.

Regarding to the cognitive performance (CP), it was used the application scores of the psychological tests of the Rehabilitation Center participants medical records. The same occurred with the scores obtained in the Motor Disturbance Gravity Scale (MDG) and social-economic analysis (inferior low, superior low and average level).

The Speech and Hearing Pathology evaluation consisted of anamnesis; communicative behavior observation (CBO) involving playful, interactive and dialogical activities, filmed for posterior analysis; Peabody Picture Vocabulary Test PPVT(24) and Illinois Test of Psycholinguistic Abilities - ITPA(25) application, following the criteria of analysis foreseen in tests manuals. The CBO session was used to verify if the children presented understanding, attention in the activities, intentionality, among other behaviors that made possible the activities proposals accomplishment. Regarding to the expression, it was used the classification(26): Degree 1: The articulation defects are insignificant; Degree 2: Although the patient articulate with difficulty, everyone understand him; Degree 3: Considering the difficulties in the articulation, only the family or professionals used to this type of difficulty understood the patient; Degree 4: The alterations became impossible the verbal expression. Degree 1 had been considered in $25 \%$ of the participant, Degree 2 in $50 \%$ and Degree 3 in $25 \%$.

In the Picture 1 is presented the participants characterization regarding to the chronological age, gender, school type and CP.

The statistical description consists of the relative and absolute values distribution, in minimum and maximum values, average, medium, $1^{\circ}$ and $3^{\circ}$ quartile $(\mathrm{Q})$, standard deviation (SD) and no parametric tests application of Spearman and Wilcoxon (significance level of $\mathrm{p} \leq 0,05$ ). 
CHART 1. Chronological age, gender, school type and CP characterization.

\begin{tabular}{|ccccc|}
\hline \hline \multirow{2}{*}{ Participant } & Age & Gender & School & CP \\
\hline 1 & $6 \mathrm{a}$ & Masculine & PS & $5 \mathrm{a} 11 \mathrm{~m}$ \\
2 & $4 \mathrm{a} 2 \mathrm{~m}$ & Masculine & PS & $4 \mathrm{a}$ \\
3 & $4 \mathrm{a}$ & Feminine & PS & $4 \mathrm{a}$ \\
4 & $5 \mathrm{a}$ & Masculine & MS & $3 \mathrm{a} 11 \mathrm{~m}$ \\
5 & $5 \mathrm{a} 8 \mathrm{~m}$ & Feminine & OS & $4 \mathrm{a} 11 \mathrm{~m}$ \\
6 & $5 \mathrm{a}$ & Masculine & MS & $4 \mathrm{a} 2 \mathrm{~m}$ \\
7 & $4 \mathrm{a} 4 \mathrm{~m}$ & Masculine & MS & $3 \mathrm{a} 6 \mathrm{~m}$ \\
8 & $4 \mathrm{a}$ & Feminine & OS & $4 \mathrm{a}$ \\
\hline \hline
\end{tabular}

TABLE 1 . Receptive-auditory vocabulary characterization in accordance with the categories of the PPVT.

\begin{tabular}{ccc}
\hline Categories & $\mathbf{N}$ & Porcentage (\%) \\
Extremely low & 0 & 0.0 \\
Moderataly low & 1 & 12.5 \\
Low médium & 3 & 37.5 \\
Medium & 1 & 12.5 \\
High médium & 2 & 25.0 \\
Moderataly high & 1 & 12.5 \\
Extremely high & - & - \\
\hline Total & 8 & 100.0 \\
\hline
\end{tabular}

\section{Results}

The PPVT scores obtained are described in Table 1.

The correlation between the CP scores and the PPVT values through the Spearman test were $\mathrm{R}=$ 0.63 and $p=0.0074$, showing statistical significance.

Table 2 presents the the Wilcoxon test result for the comparison between ITPA auditory and visual subtests, considering de PA, showed statistically significant values only for PA-AA \& PA-VA, $\mathrm{p}=0.05057$ (PA-AR \& PA-VR: $\mathrm{p}=1.124185$ and PA-ASM \& PA-VAM: $\mathrm{p}=0.28325$ ).

The Spearman test result for the correlation of PPVT and ITPAAR subtest, regarding the PA, was statistically significant $(R=0.67$ and $p=0.005830)$.

The Wilcoxon test result for the comparison between ITPA auditory and visual subtests, considering de PA, showed statistically significant values only for PA-AA\& PA-VA, $\mathrm{p}=0.05057$ (PA-AR \& PA-VR: $\mathrm{p}=1.124185$ and PA-ASM \& PA-VAM: $\mathrm{p}=$ 0.28325). The Spearman test result for the correlation of PPVT and ITPAAR subtest, regarding the PA, was statistically significant $(\mathrm{R}=0.67$ and $\mathrm{p}=0.005830)$.

TABLE 2. ITPA subtests distribution, considering PA, regarding to the avarage, medium, minimum, maximum, 1st and 3rd Q and SD values.

\begin{tabular}{cccccccc}
\hline \hline Variables & Avarage & Medium & Minimum & Maximum & $\boldsymbol{1}^{\text {st }}$ & $\boldsymbol{3}^{\text {rd }}$ & SD \\
& & & & & $\boldsymbol{Q}$ & $\boldsymbol{Q}$ & \\
\hline PA-AR & 38.0 & 31 & 23 & 60 & 26 & 48 & 14.0658 \\
PA-VR & 50.5 & 33 & 26 & 120 & 27 & 60 & 33.0635 \\
PA-AA & 30.5 & 25,5 & 23 & 46 & 23 & 37 & 8.0264 \\
PA-VA & 37.6 & 39 & 23 & 56 & 30 & 45 & 10.3449 \\
PA-VE & 25.9 & 23 & 23 & 39 & 23 & 26 & 5.1659 \\
PA-ME & 40.7 & 30 & 23 & 78 & 23 & 58 & 21.0619 \\
PA-GC & 32.8 & 25 & 23 & 69 & 23 & 43 & 13.9882 \\
PA-AC & 33.5 & 23 & 23 & 58 & 23 & 47 & 15.0062 \\
PA-VC & 48.6 & 48 & 23 & 130 & 23 & 60 & 30.1014 \\
PA-ASM & 27.1 & 23 & 23 & 48 & 23 & 32 & 7.2202 \\
PA-VSM & 32.2 & 23 & 23 & 54 & 23 & 51 & 13.6505 \\
PA-SC & 24.6 & 23 & 23 & 32 & 23 & 23 & 3.3879 \\
\hline \hline
\end{tabular}

Auditory Reception (AR); Visual Reception (VR); Auditory Association (AA); Visual Association (VA); Verbal Expression (VE); Manual Expression (ME); Grammatical Closure (GC); Auditory Closure (AC); Visual Closure (VC); Auditory Sequential Memory (ASM); Visual sequential Memory (VSM) and Sounds Combination (SC). 
The Spearman test results for the comparison between MDG and ITPA subtests, considering the $\mathrm{PA}$, was statistically significant for MDG \& PA-AR $(\mathrm{R}=-0.66 ; \mathrm{p}=0.010), \mathrm{MDG} \& \mathrm{PA}-\mathrm{VR}(\mathrm{R}=-0.66 ; \mathrm{p}=$ $0.008), \mathrm{MDG} \& \mathrm{PA}-\mathrm{AA}(\mathrm{R}=-0.68 ; \mathrm{r}=0.006), \mathrm{MDG} \&$ $\mathrm{PA}-\mathrm{ASM}(\mathrm{R}=-0.54 ; \mathrm{p}=0.042), \mathrm{MDG} \& \mathrm{PA}-\mathrm{VSM}(\mathrm{R}=$ $-0.57 ; \mathrm{p}=0.032)$, MDG \&PA-GC $(\mathrm{R}=-0.76 ; \mathrm{p}=0.001)$, $\mathrm{MDG} \& \mathrm{PA}-\mathrm{AC}(\mathrm{R}=-0.54 ; \mathrm{p}=0.042), \mathrm{MDG} \& \mathrm{PA}-$ $\mathrm{VC}(\mathrm{R}=-0.27 ; \mathrm{p}=0.034)$ and $\mathrm{MDG} \& \mathrm{PA}-\mathrm{SC}(\mathrm{R}=-$ $0.49 ; \mathrm{p}=0.053)$, but not for MDG \& PA-VA $(\mathrm{R}=-$ $0,44 ; \mathrm{p}=0,110)$.

\section{Discussion}

In the receptive vocabulary characterization (Table 1), $87.5 \%$ of the casuistry presented scores among low medium and extremely high. In spite of children with D-CP, present damages or limitations to explore the environment in an independent way, suggesting damages probability in language development(11-12,21,23), it is possible to infer that the participation in rehabilitation programs, in the most tender age, with school attendance, might have influenced positively the vocabulary acquisition. Besides, the vocabulary acquisition can't be directly related to the motor skills, but to the children's interaction degree with other people(27). The present multifatorial character in language acquisition should also be analyzed and accompanied in the children language development(28). Acquiring concepts is extremely related to the opportunities that the environment offers, beyond obviously, to the intrinsic subjects as motivation, maturation, sensorial integrity and anatomical integrity of the central nervous system (CNS)(12, 21-22).

The correlation of CP and PPVT scores indicated that the better cognitive scores, better scores in the vocabulary. Studies that analyzed the vocabulary, correlated this ability to the $\mathrm{CP}$, for the narrow relationship between language and $\operatorname{cognition}(2,4,13)$. The learning process involving language and cognition is dynamic and continuous in time, and it has been provided by the nervous system maturation, depending on the interaction of innumerable factors. When the children have opportunity to act with freedom in the environment, gradually they are going assimilating and organizing their experiences and structuring their potentialities. The presence of alterations in the motor area, limits the children, making that their acquisition rhythm suffers significant influences, in the cognitive, interpersonal and linguistics abilities. On the other hand, the lesion area influence is also relevant, because even with the environmental conditions providing the stimulus for the development, we can 't deny its correlation. Reflections about the PVL, are presented in studies $(4,8,14)$.

In the descriptive analyze of the ITPA variables it is possible to observe the variability in each subtest answers, confirm the literature that presents D-CP individuals form a heterogeneous group as for the performance in psycholinguistics activities(4, 7, 16). Analyzing the avarage and medium, respectively, in the visual and auditory abilities, the indexes of successes were modest. Also in the tests involving sequential memory, the participants obtained better indexes in the visual abilities. However, the values of the medium brought relevant information, because comparing with the data presented in the 1 st and $3 \mathrm{rd} \mathrm{Q}$, the scores were lower, indicating poor performance. The same happened in the SC subtest, in which they demonstrated higher damage. In the expression tests they presented better performance in the manual activities than in the verbal ones. Comparing the descriptive measures, it is observed that the participants had better scores in tests that demanded information reception than expression. The tests where the participants had the worst scores were the ones that demanded SC, following by the VE and ASM. The ASM subsidizes the SC, which is influenced by the abilities of oral expression, promoting the feedback and the information integration.

The perceptive development, in individuals with D-CP, needs to be better understood(4, 7, 16-18). In the sensorial-motor development, the functional exercise and the motor action organization are related to proprioceptives experiences and the visual and auditory system performance that is in charge of mobilizing with ocular, the head and the body movements, through the reactions of gaze at environmental stimulations. The vestibular system performance together with the tactile proprioceptives, visual and auditory sensations is responsible for the activation and development of the neurons processes, that takes the perception and orientation in the space, because they offer subsidies for the children in the integration of the balance, gait, harmonious movements and appropriate posture, besides the management of the activities to be learned(29). The perceptive development depends on the sensorial-motor experiences quality lived by the children, on his elaboration and organization, beyond obviously, on the anatomofunctional aspects of the nervous system. In this sense, children D-CP may present 
damages in the development and, disadvantages in abilities acquisition that involve the stimulations reception, the integration of the same ones and the expression through motor actions. Considering that the D-CP related to the PVL tends to affect descendants fibers motor of the association cortex and association fibers of the visual, auditory and somesthesics functions(15), special attention should be given in the therapeutic planning for the development of auditory and visuals abilities.

The participant's motor damage in these ASM and VSM subtests wasn't considered relevant because only $25 \%$ presented expression alteration of degree 3 and by definition, the D-CP is characterized by bilateral compromising, involving the four members, with prevalence of alterations for the inferior members $(1$, $13,20)$. The memory designates the capacity to acquire, to keep and to remind information. It refers to the use of storage mechanisms of information through CNS actions(29). Studies involving memory in DCP individuals presented that they demonstrated damages $(4,14,22)$.

In the SC test, the participants obtained very low scores. This test involves phonological conscience work. It is inferred that the motor disturbance has influenced these results even for the individuals that presented better scores. The phonological abilities tend to get better with the age and maturational process progress. As these children are in preschool age, attention must be given to the intention of favoring the abilities development for the reading and writing learning. In the closure tests, the participants didn't present good performance as well, however in VC, they had better scores. Study(8) involving visual perception in children with D-CP and PVL, presented that there were individual differences, confirming these individuals' heterogeneity in visual perceptive activities. In general, these obtained better scores in tasks of visual perception than visual-motor coordination. The participants also failed in the closure subtests indicating difficulties to integrate individual parts in an image and better scores in recognition of objects. These founds were also observed in this study.

In the comparison of the AR and VR, AA and VA, and ASM and MSM, considering the PA, it was observed that although the significant correlation was only for the comparison AA and $\mathrm{VA}$, in the others, the value of $\mathrm{p}$ indicated a tendency. Somehow, for the Table 2, comparing the average and medium for the focused variables, it is possible to observe, in spite of more modest performance in these abilities, better scores in the activities that involved visual abilities than auditory.
It is inferred that these discoveries are related, among other variables, to anatomofisiologicals subjects. Children of very low weight with periventricular lesions present alterations in the acquisition of auditory abilities, as well as alterations in the auditory processing, being translated in learning difficulties $(2,4,11)$. On the other hand, studies with individuals that present periventricular lesions associated to the PVL and visual abilities, referred the high incidence of visual problems, mainly perceptive visual disorders, that can be an expression of the parieto-occipital area bad operation, that favor the integration of the visual stimulations $(3,8,14,22)$.

The correlation between the PPVT and ITPAAR subtest, indicated significant correlation. Stimulations reception involves complex processes initiated through attention mechanisms. The attention orientation to a certain place or stimulus is usually accompanied by eye, head and body movements, producing what is denominated of orientation or exploratory behavior, allowing to the CNS to identify the stimulation source with the objective of make the organism to react to it(29). From this principle, that involves receptive development, it is expected that individuals whose presents neuropsychomotor development delay and pathological reflexes as the cervical tonic reflexes, present alterations in activities that involve stimulations reception. On the other hand, the understanding of these difficulties by the relatives can make them return to their difficulties, as is described in literature(21). The information, actions and experience reaches children, although, for the stimulation environment preparation. The importance of the context and the interpersonal relationships is stood out, because these will be essential in the meanings determination, in the stimulators promotion to invoke the motivation in communicative activities, as well as to favoring the neuronal processes development, affecting the CNS maturation and plasticity.

The statistically significant correlation among the MDG and ITPA subtests, regarding to the PA, indicated that as larger the motor disturbance worse the scores obtained, except in the VA subtest. There is correlation between the motor disturbance gravity and difficulties in linguistic abilities (4, 7, 11-12, 1820), epilepsy(23) and visual abilities(6-7, 10, 13). It is possible to infer that the statistically significant relationship wasn 't evidenced, in the referred test, because the activity of visual association is a superior mental function that little depends on the motor performance, mainly after the function to be established or in process. 


\section{Conclusion}

It was found a great variability of the participants' answers demonstrating that, individuals with D-CP don't really form a homogeneous group. In the individual results, the importance of this study is also the possibility of therapeutic plans structured for the communicative needs, psycholinguistics abilities development, considering the sequel in the presence of PVL.

\section{References}

1. Himmelmann K, Hagberg G, Beckung E, Hagberg B, Uvebrant P. The changing panorama of cerebral palsy in Sweden. IX. Prevalence and origin in the bird-year period 195-1998. Acta Paediatr. 2005;94(3):287-94.

2. Alegría A, Pittaluga E, Mena P, Schlack L, Dias MM, Vergara SD. Evolución neurosensorial en recién nacido de muy bajo peso de nacimiento a los 2 años de edad corregida. Rev Chil Pediatr. 2002;37(4):348-56.

3. Grupta AMA, Aggarwal R, Sreenivas V, Paul VK, Deorari AK. Incidence of periventricular leukomalacia among a cohort of very low birth weight neonates. Indian Pediatrics. 2006;43(17):210-6.

4. Downie AL, Frisk V, Jakobson LS. The impact of periventricular brain injury on reading and spelling in the late elementary and adolescent years. Child Neuropsychol. 2005;11(6):479-95

5. Tang-Wai R, Webster RI, Shevell MI. A clinical and etiologic profile of spastic diplegia. Pediatric Neurology. 2006;34(3):212-8.

6. Costa MF, Salomão SR, Berezovsky A, Haro FM, Ventura DF. Relationship between vision and motor impairment in children with spastic cerebral palsy: new evidence from electrophysiology. Behavioral Brain Res. 2004;149(2):14550 .

7. Bonifacci, P. Children with low motor abilities have lower visual motor integration abilities but unaffected perceptual skills. Human Mov Sci. 2004;23(2):157-68.

8. Fazzi E, Bova SM, Uggetti C, Signorini SA, Bianchi PE, Marauci I, et al. Visual - perceptual impairment in children with periventricular leukomalacia. Brain Dev. 2004;26(8):506-12.

9. Porro G, Van Der Linden D, Nieuwwnhuizen O, WittebolPost, D. Role of visual dysfunction in postural control in children with cerebral palsy. Neural Plast. 2005;12(23):205-10.
10. Madan A, Jan JE, Good W. Visual development in preterm infants. Dev Med Child Neurol. 2005;47(1):27680 .

11. Lamônica DAC. Habilidades Psicolingüísticas em crianças com Paralisia Cerebral Diplégica. [Tese de Livre Docência]. Bauru (SP): Faculdade de Odontologia de Bauru; 2006.

12. Pirila S, Mere J, Pentikainen T, Ruusu-Niemi P, Korpela $\mathrm{R}$, Kilpinen $\mathrm{J}$, et al. Language and motor speech skill in children with cerebral palsy. J Commun Disorders. 2007;40(2):116-28.

13. Bataglia M, Russo E, Bolla A, Chiusso A, Bertelli S, Pelegri A. International classification of functioning, disability and health in a cohort of children with cognitive, motor and complex disabilities. Dev Med Child Neurol. 2004;46(1):98-106.

14. Crespo-Eguiláz N, Narbona J. Habilidades neurocognitivas de niños con leucomalácia periventricular. Resultados preliminares em 15 sujetos. Rev Neurol. 2004;38(Suppl 1):80-4.

15. Krägelow-Mann I, Horber V. The role of magnetic resonance imaging in elucidating the pathogenesis of cerebral palsy: A systematic review. Dev Med Child Neurol. 2007;49(2):144-51.

16. Waelvelde H, Weerdt W, Cock P, Smitth-Engelsman B. Association between visual perceptual deficits and motor deficits in children with developmental coordination disorders. Dev Med Child Neurol. 2004;46(10):661-6.

17. Shapiro B. Cerebral palsy: A reconceptualization of the spectrum. J Pediatr. 2004;14(2):3-7.

18. Michelsen SI, Uldall, P, Madsen M. Education and employment prospects in cerebral palsy. Dev Med Child Neurol. 2005;47(8):511-7. 
19. Lamônica DAC, Chiari BM, Pereira LD. Avaliação do processo receptivo de crianças paralíticas cerebrais: aspectos auditivos e lingüísticos. Iberoamericana Info Cient [periódico na internet]. Revista Eletrônica Socied; 2003. [citado em 8 de fevereiro de 2006]. Disponível em: http:/ /www.siicsalud.com/dato/dat033/03925007a.htm.

20. Majnemer A, Mazer B. New directions in the outcomes evaluation of children with cerebral palsy. Semin Pediatr Neurol. 2004;11(1):11-7.

21. Lamônica DAC. Linguagem na paralisia cerebral. In Ferreira LP, Befi-Lopes DM, Limongi SCO. Tratado de Fonoaudiologia. São Paulo: Roca; 2004. p. 967-77.

22. Marlow N, Rose AS, Rands CE, Draper ES. Neuropsychological and educational problems at school age associated with neonatal encephalopathy. Arch Dis Child Fetal Neonatal. 2005;90(5):380-7.

23. Kulak W, Sobanieh W, Kuzia JS, Kubas B, Walecki JA. Comparasion of spastic diplegic and tetraplegic cerebral palsy. Pediatr Neurol. 2005;32(5):311-7.
24. Dunn LM, Padilla ER, Lugo DE, Dunn LM. Test de vocabulário por Imágenes Peabody (Peabody Picture Vocabulary Test). Manual del examinador. Adaptação Hispanoamericana. American Guindance Service Publishers' Building, Circle Pines: Minessota; 1986.

25. Bogossian MADS, Santos MJ. Manual do examinador: Teste Illinois de Habilidades Psicolingüísticas. Rio de Janeiro: EMPSI; 1977.

26. Sanclemente MP. Problemas de linguagem na paralisia cerebral. Diagnóstico e tratamento. In: Puyelo-Sanclemente M, Arguelles PP, Almirall CB, Métayer M L. São Paulo: Editor Santos; 2001. p. 17-77.

27. Pheifer LI. Comprometimento motor e aquisição de habilidades cognitivas em crianças portadoras de paralisia cerebral. Temas Desenvol. 1997;6(31):4-14.

28. Ishi C, Miranda CS, Isotani SM, Perissinoto J. Caracterização de comportamentos lingüísticos de crianças nascidas prematuras, aos quatro anos de idade. Rev CEFAC. 2006;8(2):147-54.

29. Lent R. Às portas da percepção: as bases neurais da percepção e da atenção. In: Lent R. Cem bilhões de neurônios: conceitos fundamentais de neurociência. São Paulo: Atheneu; 2001. p. 556-86. 